\title{
EchoGéo
}

48 | 2019

Illegal cannabis cultivation in the world

\section{Known Unknowns and Unknown Knowns: What we know about the cannabis and the Hashish trade in Afghanistan}

James Bradford and David Mansfield

\section{CpenEdition}

\section{Journals}

Electronic version

URL: https://journals.openedition.org/echogeo/17626

DOI: $10.4000 /$ echogeo.17626

ISSN: 1963-1197

Publisher

Pôle de recherche pour l'organisation et la diffusion de l'information géographique (CNRS UMR 8586)

Electronic reference

James Bradford and David Mansfield, "Known Unknowns and Unknown Knowns: What we know about the cannabis and the Hashish trade in Afghanistan", EchoGéo [Online], 48 | 2019, Online since 13 July 2019, connection on 31 July 2021. URL: http://journals.openedition.org/echogeo/17626 ; DOI: https:// doi.org/10.4000/echogeo.17626

This text was automatically generated on 31 July 2021.

EchoGéo est mis à disposition selon les termes de la licence Creative Commons Attribution - Pas d'Utilisation Commerciale - Pas de Modification 4.0 International (CC BY-NC-ND) 


\title{
Known Unknowns and Unknown Knowns: What we know about the cannabis and the Hashish trade in Afghanistan
}

\author{
James Bradford and David Mansfield
}

\section{Introduction}

1 In recent decades, Afghanistan has become synonymous with opium. Whether it is the annually-increasing quantities harvested, or the much-publicized connections to insurgent groups like the Taliban, opium is center-stage in the contemporary narrative of Afghanistan. And yet, opium is but one of a broader mosaic of drugs that include heroin, alcohol and more recently methamphetamine, that comprise the illicit drug economy and Afghan drug culture. One of those drugs, cannabis, has a long history of cultivation and use, longer than opium in fact, and to this day, is grown widely and used extensively throughout Afghanistan. Yet, little is known about cannabis, and significant questions remain about its history, its cultural impact, and its enduring presence in the illicit economy of Afghanistan.

2 In this chapter, we seek to explore how, why, and in what ways cannabis shaped, and continues to shape, the illicit drug trade in Afghanistan and consumer markets around the world. First, by analyzing the historical antecedents of the contemporary cannabis trade we will demonstrate that the Afghan cannabis trade was increasingly influenced by the demands of the global market, laying many of the foundations seen in the industry today. In particular, during the 1960s and 70s, Western hippies and drugtrafficking entrepreneurs traveled to Afghanistan in search of high-quality Afghan hashish that had become an attractive brand for Western consumers. The demand for Afghan hashish pushed many producers to alter methods of production to meet the ever-increasing appetite. Second, we will demonstrate why, in recent decades, cannabis 
still remains an enduring component of the Afghan drug trade. Unlike the 1960s, or during the reign of Amanullah Khan, when Afghan authorities embraced cannabis, the emergence of the Taliban and the subsequent US invasion following the attacks of 9/11, complicated the role cannabis plays within Afghanistan. Despite claims by the United Nations that Afghanistan is the largest hashish producer in the world, the political, economic, and security issues on the ground present a far more varied, and complicated picture. Little is known about the precise amounts of cannabis cultivated, nor where, as cultivation is highly dispersed and interwoven with other agricultural products. What is known, however, is that cultivation and trade has ebbed and flowed as various political factions have either prohibited cultivation or relaxed controls. Furthermore, the prevalence of cannabis cultivation and trade is dependent on local prices and competition, which can influence the extent to which cannabis will be grown as a primary, secondary, or even tertiary agricultural commodity.

Ultimately, the precise features and contours of the Afghan cannabis trade are, and always have been, nebulous: where, how much, and why cannabis is cultivated is unpredictable and varied. And yet, what we do know is that cannabis is grown widely, hashish is exported to regional and global markets, and the industry remains an enduring element of the Afghan drug trade and Afghan economy.

\section{Methodology}

4 The prevalence of cannabis, especially hashish, as both a domestic and global good in Afghan history, is critically understudied, despite being important to the growth of the illicit opium trade that flourishes in Afghanistan. As an historian, one of the authors expands upon Afghan history, as well as the history of the illicit global drug trade, which has focused predominantly on the Afghan-Soviet war as the transformative period for the history of drugs in Afghanistan. Based off of archival research conducted at the National Archives in the US (NARA II), the UK National Archives at Kew, and the National Archives of Afghanistan (Arshif-e-Milli) in Kabul, this paper argues that the opium and hashish trades have a much longer and more complicated history than previously assumed. Emphasizing the entanglements with the colonial trade of drugs in British India during the early parts of the 20th century, as well as the evolving nature of production and trade in the 1960s and 1970s, Afghan cannabis and hashish were slowly drawn into the shifting global marketplace, laying the foundations for networks that would eventually ship heroin throughout the world.

5 Work on the contemporary cannabis economy draws on in-depth research in Afghanistan by one of the authors over many years. This body of research primarily focused on the changing role of opium poppy cultivation within the wider livelihoods of farmers in different parts of the country, especially in the provinces of Helmand, Kandahar, Nangarhar, Badakhshan, and Farah. Cannabis, like opium, is just one crop amongst many grown, and one activity of a multitude that a rural household undertakes in pursuit of its livelihood. Experience has shown that research on both opium poppy and cannabis needs to examine the portfolio of activities that a household is involved in, as well as the wider socio-economic and political environment, to better understand the factors and conditions that lead to illicit drug crop cultivation (Mansfield, 2016b). This livelihood approach mitigates some of the challenges of conducting research on illicit or underground activities: it avoids direct questioning on 
drug crop cultivation - "drugs fetishism" - and the biases that arise, and provides a framework from which to verify the data produced on opium and cannabis cultivation.

\section{History}

6 Little is known about precisely when, where, and how cannabis use and cultivation first began in the region. However, Afghanistan is believed to have one of the oldest continuous cannabis cultures in the world, which is reflected in the diversity of cannabis-based products found throughout the country. Although cannabis is grown widely, most Afghans prefer not to consume the dried flowers, known as ganja (marijuana in the West). Rather, most Afghans prefer to smoke the local form of hashish: charas (pronounced chaars in Afghanistan). Charas is native to Central Asia, and is made by sieving the resin glands of the cannabis plant and then storing it in a leather pouch to cure (the word charas is believed to derive from Persian word for leather pouch). Much of the historical basis for Afghan cannabis stems from the oral mythologies and tales of the legendary Baba $\mathrm{Ku}$, who centuries ago roamed the mountains of Central and South Asia using cannabis and hashish as vehicles to heal the spiritual and physical ailments of those in need. In more recent decades, babas, local spiritual and religious teachers, endeavored to preserve the ethos of Baba Ku through the use and distribution of hashish (Clarke, 2010). Cannabis became a mainstay product during the Mughal dynasty (1526-1857), where numerous leaders, including the founder of the dynasty, Zahiruddin Muhammad Babur, encouraged the cultivation, production, and use of various forms of cannabis and hashish (Honchell, 2012).

7 It was not until the late nineteenth century that the Afghan cannabis trade became increasingly entangled with the global trade in drugs. In particular, the thriving opium and cannabis markets in British India played an important role in luring Afghan producers and smugglers to markets southward. During the reigns of both Abdur Rahman Khan (1882-1901) and Amanullah Khan (1919-1928) they recognized and embraced the viability of cannabis-based products, such as charas and bhang (a paste made from cannabis and consumed in foods or drinks), as export goods, encouraging production and trade, all the while, establishing excessive taxes and strict punishments for production and use that was intended for the domestic market. Abdur Rahman, in an attempt to profit from the large demand for cannabis and opium in British India, reduced taxes on exports to increase trade to the south. In turn, most of the charas and opium found in the markets of the Northwest Frontier Province were coming from Afghan traders to the north (Bradford, 2019).

8 Amanullah Khan's tenure as ruler of Afghanistan was characterized by attempts to rapidly reform and modernize the political, economic, and legal systems. In an effort to discourage Afghans from using and trading cannabis products, as well as other drugs, inside the country, Amanullah enacted the Penal Code of 1924-25, which put forth a series of strict punishments for users and suppliers (Gregorian, 1969). A 50 percent tax was placed on the distribution of charas, and bhang, and users could receive up to 39 lashings. However, similar to Abdur Rahman before him, Amanullah also sought to take advantage of the Indian market, and reduced export taxes on cannabis and opium exports, even exempting traders from the harsh punishments of the Penal Code, as long as the products were destined for markets outside Afghanistan (Bradford, 2019). What impact the countervailing domestic and foreign policies had on the precise locations of 
cannabis cultivation and production of charas within Afghanistan is less clear. According to the Russian botanist Nikolai Vavilov, in the 1920s cannabis was found throughout the northern regions in Badakhshan and western regions around Herat, although cultivation was present in other parts of the country (MacDonald, 2007). Nonetheless, the dual policy established by Amanullah had a tremendous impact inside British India. Cannabis and opium that were legally produced in British India were taxed heavily by colonial officials and local authorities, and even though a market existed for Afghan cannabis to be traded legally, it too was taxed inordinately. As a result, the smuggling of Afghan hashish became a growing problem for British authorities as drugs produced in British India were so heavily taxed that they could not compete with the smuggled cannabis and opium from Afghanistan. Eventually, the dual system, which both rulers embraced, contributed to the tightening controls over foreign and domestic opium and cannabis products in British India. More important, Afghan cannabis began to make its way to markets beyond its borders (Bradford, 2019).

It was in the 1960s that the cannabis industry in Afghanistan would undergo its next significant evolution. Throughout this decade, thousands of travelers, many of whom were part of the counter-culture movement which was gripping much of the Western world, ventured through Afghanistan via the "Hippie Trail" (Maguire and Ritter, 2014). The trail, which began in Morocco or Turkey, and flowed through Iran and Afghanistan, and ended in India or Nepal, was a catalyst for the changing contours of the Afghan cannabis industry. This was due in part to the fact that many of those travelers found Afghanistan to be an ideal stop on the trail, particularly because of its cheap and abundant hashish. In many ways, Afghanistan was ideal for Western hippies. Although, cannabis and hashish were illegal, Afghan authorities rarely enforced the law (Charpentier, 1973). In many of the major cities, hotels catered to travelers in search of high-quality hashish. In Kabul, the Noor and Mustafa hotels provided safe havens for hash smokers, and in the stalls of merchants on Chicken Street in the Shawr-e Naw district, travelers could easily find cheap potent hash. Special teahouses (saqikhana) that catered exclusively to charas users could be found in Kandahar, Herat, or Mazar-iSharif. American consular officials estimated that there were up to 25 variations of hashish being sold in markets around the country, many of which far surpassed American cannabis products in terms of levels of THC, and were clearly indicative of the vitality of the Afghan hashish market (Bradford, 2019).

10 Although larger and larger numbers of hippies descended upon Afghanistan throughout the 1960s, Afghan cannabis cultivation and hashish production were initially ill-suited to meet demand. Traditionally, cannabis farmers did not use chemical fertilizers and hashish was produced manually using sieves or rugs to extract the resin powder from the cannabis flowers. Despite the fact that production was labor intensive the hashish itself was of superior quality and potency. Marked by a government that rarely enforced anti-drug laws, as well as a local culture that viewed hashish use with either indifference or ambivalence, Afghanistan was an ideal stop on the "Hippie Trail", and more important, for the burgeoning hashish trade. Thus, by the end of the 1960s, Afghanistan was established as one of the world's main sources of topquality hashish (Clarke, 2010).

11 Things would change in the 1970s. In May of 1970, counter-narcotics agents raided the Shak-i-Foladi Hotel in Kabul, arresting thirteen people and confiscating nearly 200 grams of hashish. Although the quantity was rather small, the drug bust marked a 
significant evolution in the nature of the drug trade in Afghanistan, as those arrested were not hippies, but a new professional class of traffickers. Thus, it was during the 1970s that these entrepreneurs linked Afghan production with demand to larger markets elsewhere, and Afghanistan evolved from a drug destination to a drugtrafficking hub (Bradford, 2019). For many Afghan and American counter-narcotics officials, it was the growing presence of the Brotherhood of Eternal Love that was indicative of the growing dimensions of the Afghan drug trade. Dubbed the "hippie mafia', the Brotherhood had become well established in America as some of the primary traffickers of hashish and cannabis into the United States, and they were in some ways responsible for fueling the counter-culture movement (May and Tender, 2008). In Afghanistan, the Brotherhood was taking full advantage of the lax enforcement of laws to bring high-quality hash to the West. According to European traffickers, the Brotherhood was most responsible for the big changes in both the production and sale of hashish. Allegedly, members of the Brotherhood paid double or triple the amount for a gram of hashish, and began to drive market prices up throughout the country (Clarke, 2010). The impact of the Brotherhood and like-minded traffickers was that to respond to the shifting and growing demand, more and more Afghans got involved in the cultivation of cannabis and production of hashish.

The changing dynamics of the cannabis trade, as it shifted from local demand to global traffickers, led to major changes in the production of hashish. To meet demand, many producers shifted to methods that were more advantageous for producing greater volumes of hashish, however, at the expense of quality. For example, some producers abandoned the cloth sieves that took longer to extract the cannabis resins in exchange for metal sieves, which could sieve more material but would often reduce the potency because excess plant material would remain throughout the powdered resin. To increase volume, some traffickers would mix lower quality resins with those of higherquality, in turn, reducing the overall potency of the hashish. Others added oils to mimic the texture and consistency of primo hashish, mainly to make it feel sticky, but were otherwise masking the deficiencies in the product (Clarke, 2010). Afghans, nonetheless, were generally responsive to the changing clientele and their demands. By the 1970s, the growing presence of traffickers were not only willing to pay well above market value, but also were willing to invest in the mechanization of cannabis cultivation, such as providing money to purchase tractors or fertilizers, as well as, providing resources to scale-up hashish production, in the form of metal sieves and oils. Furthermore, the changes in production, which were compelled by the need for more quantity, were even being motivated by the government. Some farmers claimed that in 1969, King Zahir Shah, in contravention of Afghan laws which prohibited cultivation, production, sale, and use, sent out official edicts encouraging farmers to use fertilizers to increase yields of cannabis (MacDonald, 2007). In effect, the increasingly global demand for Afghan hashish ultimately reduced the availability of the top-quality hashish that had made Afghanistan such a major destination on the hippie trail. However, it did link Afghan hashish to markets beyond more localized demand in Afghanistan, as well as, south and southwest.

13 By late 1970s, and early 1980s, Afghan hashish remained a lucrative commodity in Afghanistan. Even with the onset of the Afghan-Soviet War, which broke out in 1979, hashish remained in high demand, indicating how cannabis would remain an important part of the Afghan drug economy during the following four decades of war. 


\section{Contemporary}

14

estimates are a consequence of the international community's focus on opium production. After all, both UNODC and United States Government surveys, as well as the overall anti-drugs effort in Afghanistan have focused almost exclusively on opium production and given only wavering attention to cannabis. However, the challenges of measuring the extent of cannabis cultivation are much more fundamental than that of policy makers pursuing a single crop focus and ignoring the cannabis crop. Most are methodological. For example, the crops dispersal across Afghanistan makes both census and sample surveys difficult and costly. Its growing season, over the spring and summer, as well as its leafy appearance, presents significant challenges differentiating cannabis from the numerous other crops grown over the same period. In Afghanistan, cannabis can also be grown alongside or interspersed with other crops, making accurate visual assessments of area either from the ground or by remote sensing, difficult (UNODC, 2008, p. 6).

A second reason for doubting the assertion that Afghanistan had become the largest producer of hashish was the way that the results of data collection methods were mixed in the UNODC survey that underpinned the claim. From 2009 until 2011 UNODC's cannabis survey for Afghanistan used a combination of methods and produced a wide range of estimates (see illustration 1). For instance, in 2010 the estimate ranged from 9,000 hectares to 29,000 hectares of cannabis cultivation (UNODC, 2011, p. 6). The lower figure in the range was based on remote sensing, the higher figure was drawn from a ground survey; both were viewed as having a high degree of uncertainty (UNODC, 2011, p. 51; UNODC, 2013, p. 9; former UK government official, personal communication, December 2018). In 2012, UNODC moved to a "satellite based survey" which they argued would allow "more robust estimates" (UNODC, 2013, p. 9). However, UNODC drew its sampling frame from the potential active agricultural area during the winter months, not the summer when cannabis is actually grown in Afghanistan - and a period when the agricultural area is significantly reduced (UNODC, 2013, p. 27). Concerns over the efficacy of the results and ultimately the integrity of the survey led to the survey being abandoned (former UK government official, personal communication, December 2018). 
Illustration 1 - UNODC estimate of cannabis cultivation, 2009-2012

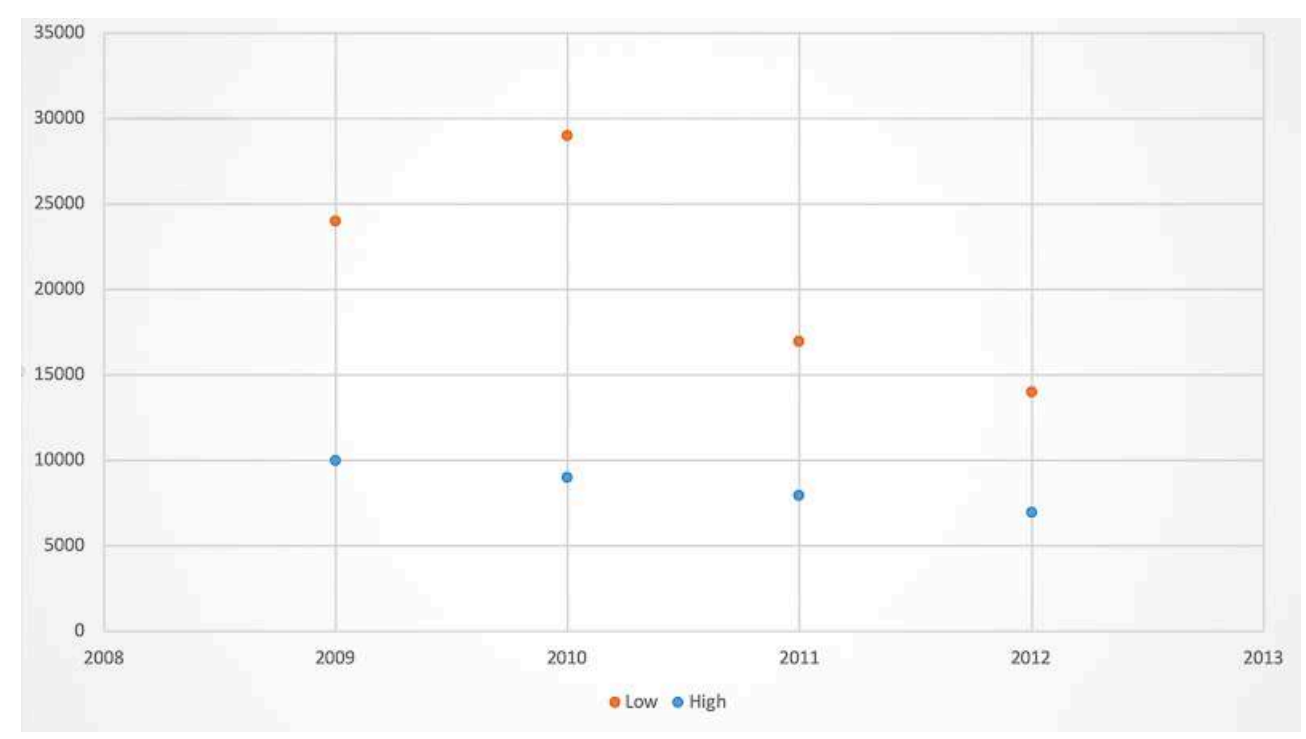

Source: UNODC 2008, 2010, 2011 \& 2013.

Given the high degree of uncertainty in these national estimates the question is what do we actually know about cannabis cultivation in contemporary Afghanistan?

The first point to note is the fact that the crop has not been neglected by the Afghan authorities as much as it has been by the international community. The cannabis crop has in fact been subject to a number of restrictions over the years. As mentioned above, the Taliban banned cannabis production early on in their rule and long before their successful imposition of a ban on opium production in 2000/01. They argued that the production and consumption of cannabis was un-Islamic and as opposed to their earlier proclamations on the prohibition of opium in 1994,1997, and 1998, the ban on cannabis appears to have been effective in the areas where they dominated.

20 Subsequently a ban on cannabis cultivation was imposed in the northern province of Balkh under the leadership of Governor Noor Mohammed Atta in 2008, after, and then alongside, his successful prohibition of opium between 2007 and 2012 (Mansfield, 2009, p. 22). Localized reductions in cannabis also took place in a number of the southern districts of Nangarhar in tandem with the ban on opium imposed by Gul Aga Sherzai between 2008 and 2010 (Mansfield, 2011b, p. 3; Mansfield, 2014, p. 34-27).

Most recently, the Islamic State Khorasan (ISK) destroyed the standing cannabis crop in the Mahmand valley in the district of Achin in Nangarhar, after gaining control over the area in July 2015 (Mansfield, 2016a, p. 2). This ban on the cultivation of cannabis ${ }_{20}$ and then opium ${ }_{20}$ was maintained until the ISK abandoned the area in the spring of 2017 following the decisions by the US military forces to drop the "Mother of All Bombs" (MoAB) on the group. In the fall of 2017 the ISK forces then destroyed the harvested cannabis crop in Pirakhel and Wazir in the district of Khogiani, and as they had done in Shadal and Abdul Khel in Achin they closed down the local bazaars where hashish was being traded. In the summer of 2018, and the departure of ISK, fields of cannabis could be seen throughout Khogiani and Achin, as well as Hisrak and Sherzad (unpublished fieldwork, 2018). 
22 A second point of note is the fact that where cannabis is banned in an area following the prohibition of opium poppy, it is typically the first crop to reappear. Thus it was cannabis that was first grown in the districts of Charbolak, Chemtal and Shulgara in Balkh and across the Spinghar Piedmont of Nangarhar in the summer of 2010 before opium poppy returned to these same areas in the 2010/11 growing season (Mansfield, 2011b, p. 11). Here we can only hypothesize that it could be that cannabis cultivation is more acceptable and does not attract the same social opprobrium that opium does? Perhaps, it is farmers putting an initial foot in the water to test whether the authorities will react before they then attempt to plant opium poppy? Or maybe a loosening of the reins by the local authorities as they realize the growing economic impact of the ban on opium production and the potential for mounting resistance from rural communities (Mansfield, 2016b)? Either way in those parts of Afghanistan where both opium and cannabis are grown there is clear evidence that the re-emergence of cannabis will quickly be followed by poppy.

A third point is the extreme variability in the economic returns on chars between areas and over time. For example, drawing on in-depth fieldwork over two years in four provinces - Balkh, Helmand, Kandahar and Nangarhar - Mansfield and Fishstein (2016, p. 52-56) showed that net returns on chars varied in 2015 from US $\$ 424$ per jerib (the equivalent of US\$2,120 per hectare) in Balkh, to as much as US\$1,352 per jerib (the equivalent of US\$ 46,790) in Nangarhar. With similar and relatively low input costs across the provinces, the explanation for these dramatic differences in the profitability of chars lay with variations in regional prices and yields. Whereas in Balkh chars was still being sorted into different grades, with the first grade (awol) being sold for US $\$ 44$ per $\mathrm{kg}$, the second grade for US\$22 per $\mathrm{kg}$ and the final grade (and two thirds of the total yield) for only US\$11 per kg, the crop in Nangarhar was sold as 'mixed' for the equivalent of US\$145 per $\mathrm{kg}$. While yields of $24.75 \mathrm{~kg}^{1}$ per jerib (the equivalent $123.75 \mathrm{~kg}$ per hectare) in Balkh were more than twice that of the $12 \mathrm{~kg}$ per jerib produced in Nangarhar (the equivalent of $60 \mathrm{~kg}$ per hectare), the low prices (and extra effort required to separate the grades) received in Balkh at the time had a significant negative impact on net returns.

24 Proximity to the market in Pakistan is one possible explanation for the much higher levels of profitability in Nangarhar at the time. Indeed, Pakistan continued to hold significant influence for cannabis growers in the fall of 2018, with growing amounts of chars coming from across Nangarhar, as well as Anderab in Baghlan (but not Balkh) to be smuggled across the eastern border (unpublished fieldwork, 2018). However, in other years, prices may favour other regions. For example, in 2009 prices in Kandahar were markedly higher than in Balkh, where the prices were twice that of Nangarhar (Mansfield, 2009, p. 75). UNODC's more regional analysis reported that in 2012 prices in the North and Northeast of Afghanistan were 30 per cent higher than in the South, East, West and Central parts of the country (UNODC, 2013, p. 17).

A fourth and final point about cannabis cultivation is the continued proliferation of the crop in contemporary Afghanistan. There appears to be few geographical limits on cannabis growth and there is a growing knowledge of its husbandry in areas where the crop was not widely grown in the recent past. In Nangarhar, in eastern Afghanistan the crop is no longer limited to the upper reaches of the districts of Hisrak, Sherzad, Khogiani and Achin, it is increasingly grown in the lower parts of these districts and increasingly along the roadside. The local authorities impose no restrictions on the 
crop and in Achin cannabis is grown in close proximity to both US and Afghan Special Forces.

\section{Conclusion}

Given the overwhelming presence of opium in the Afghan economy today, cannabis is often overlooked as an integral piece of the Afghan drug economy. However, cannabis has, and still does, play a prominent role in rural economic livelihoods, and local Afghan politics. By looking at the longer historical formation of the cannabis trade, we see that over the course of the $20^{\text {th }}$ century cannabis was increasingly entangled with the growing and shifting markets for hashish. During the 1960s and 70s, especially, the demand for Afghan hashish from Western traffickers led to the increased cannabis cultivation, and larger-scale hashish production. In recent decades, cannabis cultivation remained highly dispersed, but still omnipresent within the rural Afghan economy. Despite attempts to ban and eradicate the crop by the Taliban, the Government of the Islamic Republic of Afghanistan, and more recently, the Islamic State Khorasan, cannabis cultivation persists. This is due in part to the ease with which cannabis can be grown, both intercropped with other agricultural crops, as well as its ability to be grown in various geographic zones. Ultimately, little has changed regarding cannabis in Afghanistan: it is still grown widely, has a complex relationship with groups in power, and is connected to markets globally. With a rapid increase in the price of chars in Afghanistan and Pakistan following the harvest in 2018 there is a high probability of further increases in the amount of cannabis cultivation in 2019; but as in past years there will be little sense of the actual scale of the final crop.

\section{BIBLIOGRAPHY}

Bradford J.T., 2019. Poppies, Politics, and Power: Afghanistan and the Global History of Drugs and

Diplomacy. Ithaca, NY, Cornell University Press (forthcoming).

Charpentier C.J., 1973. The Use of Haschish and Opium in Afghanistan. Anthropos, no. 68, p. 482-490.

Clarke R.C., 2010. Hashish. Los Angeles, Red Eye Press, 387 p.

European Monitoring Centre for Drugs and Drug Addiction, 2012. EMCDDA Insights: Cannabis production and markets in Europe. Luxembourg, EMCDDA, 268 p. [Online] http:// www.emcdda.europa.eu/system/files/publications/683/web_INSIGHTS_CANNABIS_350894.pdf

Fishstein P., 2015. Briefing note on Fieldwork in Balkh Province: Opium poppy and rural Livelihoods. AREU Brief, October 2015, 10 p.

Gregorian V., 1969. The Emergence of Modern Afghanistan: Politics of Reform and Modernization, 1880-1946. Stanford, CA, Stanford University Press, 586 p. 
Honchell S., 2012. Pursuing Pleasure, Attaining Oblivion: The Roles and Uses of Intoxicants at the Mughal Court. MA dissertation, University of Louisville, 628 p. [Online] https://ir.library.louisville.edu/ cgi/viewcontent.cgi?referer=https://www.google.com/\&httpsredir=1\&article=1627\&context=etd

Leggett T., 2006. Review of the world cannabis situation. Bulletin on Narcotics, vol. LVIII, $\mathrm{n}^{\circ} 1-2$, $155 \mathrm{p}$.

MacDonald D., 2007. Drugs in Afghanistan. London, Pluto Press, 320 p.

Maguire P., Ritter M., 2014. Thai Stick: Surfers, Scammers, and the Untold Story of the Marijuana Trade. New York, NY, Columbia University Press, 272 p.

Mansfield, D., 2009. Sustaining the Decline? Understanding the changes in opium poppy cultivation in the 2008/09 growing season. Unpublished Report for the Afghan Drugs Inter Departmental Unit of the UK Government, May.

Mansfield D., 2011a. The 2010/11 Opium Poppy Growing Season: An Initial Brief. Unpublished Report for the Afghan Drugs Inter Departmental Unit of the UK Government, January.

Mansfield D., 2011b. Between a Rock and a Hard Place; Counternarcotics efforts and their effects in Nangarhar and Helmand in the 2010-11 growing season. AREU Case study, 50 p. [Online] https:// areu.org.af/wp-content/uploads/2016/02/1128E-Between-a-Rock-and-a-Hard-Place-CS-2011.pdf Mansfield, D., 2014. From Bad they Made it Worse: The concentration of opium poppy in areas of conflict in the provinces of Helmand and Nangarhar. AREU Case Study, 92 p. [Online] https://areu.org.af/wpcontent/uploads/2016/02/E-NRM-CS6-ver-2-2.pdf

Mansfield, D., 2016a. The Devil is in the Detail: Nangarhar's Continued Decline into Insurgency, Violence and Widespread Drug Production. AREU Brief, February, 18 p. [On line] https:// areu.org.af/wp-content/uploads/2016/02/1602E-The-Devil-is-in-the-Details-Nangarharcontinued-decline-into-insurgency.pdf

Mansfield, D., 2016b. A State Built on Sand: How Opium Undermined Afghanistan. NYC, Oxford University Press, $382 \mathrm{p}$.

Mansfield, D. 2016c. Time to Move on: Developing an Informed Response to Opium Poppy Cultivation in Afghanistan. AREU Synthesis Paper, October, 70 p. [Online] https://areu.org.af/wp-content/ uploads/2016/12/1623E-Time-to-Move-on-Developing-an-Informed-Development-Response-toOpium-Poppy-Cultivation-in-Afghanistan.pdf

May D., Tender, S., 2008. The Brotherhood of Eternal Love: From Flower Power to Hippie Mafia: The Story of the LSD Counterculture. London, Cyan Books, $288 \mathrm{p}$.

UNODC, 1999. Double issue on cannabis: recent developments. Bulletin on Narcotics, vol. XLIX, $n^{\circ} 1-2$ \& vol. $L, n^{\circ} 1-2$.

UNODC, 2006. Review of the world cannabis situation. Bulletin on Narcotics, vol. LVIII, $\mathrm{n}^{\circ} 1-2$.

UNODC, 2008. Baseline information on cannabis cultivation, Afghanistan, December 2008. Kabul, UNODC/MCN.

UNODC, 2010. Afghanistan leads in hashish production, 31 March 2010. https://www.unodc.org/ unodc/en/frontpage/2010/March/afghanistan-leads-in-hashish-production-says-unodc.html UNODC, 2011. Afghanistan Cannabis survey 2010. Kabul, UNODC/MCN, June.

UNODC, 2013. Afghanistan Survey of Commercial Cannabis, Cultivation and Production 2012. Kabul, UNODC/MCN, September. 


\section{NOTES}

1. Of which $2.25 \mathrm{~kg}$ was grade $1,6.75 \mathrm{~kg}$ grade 2 , and $15.75 \mathrm{~kg}$ was grade 3.

\section{ABSTRACTS}

In the past four decades, much of the contemporary narrative of Afghanistan has been defined by opium. However, underneath the veil of the opium economy, the cannabis trade remains an enduring component of Afghanistan's political economy and culture. Much of this stems from the long history of cannabis cultivation and hashish production in the region. During the 1960 s, the growing demand from Western nations for Afghan hashish helped forge key global trafficking networks, as well as significant changes to the cultivation of cannabis and production of hashish. Since then, production and trade evolved, with cultivation of cannabis more widespread. Ultimately, analyzing the cannabis trade and its historical antecedents, reveals how the cannabis trade, like the opium economy, transformed in response to local, regional, and global factors, remaining an important piece of the rural Afghan economy today.

\section{INDEX}

Keywords: Afghanistan, cannabis, drug, livelihood, history, methodology, statistic, drug control, taxation

\section{AUTHORS}

\section{JAMES BRADFORD}

James Bradford, jtbradford@berklee.edu, is an Assistant Professor of History at Berklee College of Music. He recently published:

- Bradford J., 2019. Poppies, Politics, and Power: Afghanistan and the Global History of Drugs and Diplomacy. Ithaca, NY, Cornell University Press.

- Bradford J., 2019. Global Drugs Today: World Consumption and Shifting Trades. In OUP Companion to Global Drug History. NYC, Oxford University Press.

- Bradford J., 2015. Drug Control in Afghanistan: Culture, Politics, and Power during the 1958 Prohibition of Opium in Badakhshan. Iranian Studies, Vol. 48, n² 2), p. 223-248.

\section{DAVID MANSFIELD}

David Mansfield, d.mansfield@lse.ac.uk, is a Senior Fellow at International Drug Policy Unit, LSE. He recently published:

- Mansfield D., 2019. Denying Revenue or Wasting Money? Assessing the Impact of the Air Campaign Against Drugs Labs in Afghanistan, LSE IDPU, April. [Online] http://www.lse.ac.uk/ united-states/Assets/Documents/mansfield-april-update.pdf

- Mansfield D., 2018. Misunderstanding the intersection between development policies and data collection: The Experience in Afghanistan. International Journal of Drug Policy, n 58, p. 157-165. 
- Mansfield D., 2016. A State Built on Sand: How Opium Undermined Afghanistan. NYC, Oxford University Press. 